\title{
A DasA family sugar binding protein Ste2 links nutrient and oxidative stress to exopolysaccharides production in Streptomyces sp. 139
}

\author{
Mengxin Geng ${ }^{1}$, Limei $\mathrm{Ai}^{1,2}$, Ming Ma ${ }^{1}$, Panpan $\mathrm{Li}^{3}$, Lianhong Guo ${ }^{1}$, Guangzhi Shan ${ }^{3}$ and Liping Bai ${ }^{*}$
}

\begin{abstract}
Background: Ebosin is an exopolysaccharide produced by Streptomyces sp. 139, and its biosynthetic gene cluster (ste) has been previously described. Ste234 has high homology to the well-known ATP-binding cassette transport system DasABC, which has been linked to the regulation of morphological differentiation, antibiotics biosynthesis and aminosugars utilization in Streptomycetes. This study was conducted to evaluate the effect of the DasA family sugar binding protein Ste2 on Streptomyces sp. 139.

Results: The disruption of ste 2 results in the upregulation of transcription of genes within Ebosin biosynthetic gene cluster and a two-fold increase in Ebosin production. RNA sequencing data suggests that the disruption of ste2 results in the decreased utilization of carbon and nitrogen sources, increased sensitivity to oxidative stress, as well as differed strain morphology, all of which have been experimentally proven.
\end{abstract}

Conclusions: Taken together, Ste2 controls Ebosin yields, aminosugars uptake, sensitivity to oxidative stress, and morphological differentiation of Streptomyces sp. 139.

Keywords: Ste2, DasABC, Ebosin, Streptomyces sp. 139, Nutrient stress, Oxidative stress

\section{Introduction}

Exopolysaccharides (EPSs) are long-chain polysaccharides consisting of branched, repeating units of sugars or sugar derivatives, secreted by different microorganisms under stress conditions, and are not permanently attached to the cell surface [1]. The EPSs produced by bacteria are involved in multiple protective cellular functions that improve bacterial competition in different habitats [2]. Although a variety of bacterial EPSs have been

*Correspondence: lipingbai1973@163.com

${ }^{1} \mathrm{NHC}$ Key Laboratory of Biotechnology of Antibiotics, CAMS Key Laboratory of Synthetic Biology for Drug Innovation, Institute

of Medicinal Biotechnology, Chinese Academy of Medical Sciences \&

Peking Union Medical College, Beijing 100050, China

Full list of author information is available at the end of the article reported, studies of EPSs from Streptomycetes remain limited. In our previous work, a novel EPS produced by Streptomyces sp. 139, designated Ebosin (EPS 139A), has been found to possess remarkable anti-rheumatic arthritis activity in vivo [3, 4]. Also, its biosynthesis gene cluster (ste) consisting of 27 ORFs has been identified [5-7], in which Ste234 belongs to the family of ATP-binding cassette $(\mathrm{ABC})$ transporters.

$\mathrm{ABC}$ transporters couple ATP hydrolysis to the uptake and efflux of solutes across the cell membrane in bacteria [8]. $A B C$ transporters can uptake a wide variety of substances including sugars, peptides, and amino acids, allowing bacteria to monitor environmental and physiological changes, i.e., nutrient depletion, and providing the way to avoid possible damages [9]. $\mathrm{ABC}$ transporters also 
function in efflux of substances, including surface components of the bacterial cell (such as capsular polysaccharides, lipopolysaccharides, and teichoic acid), proteins involved in bacterial pathogenesis (such as hemolysin, heme-binding protein, and alkaline protease), heme, drugs and siderophores [10].

Various genes encoding oligosaccharide-uptake systems have been identified in Streptomycetes: cebEFG for cellobiose and cellotriose in Streptomyces reticuli [11]; malEFG for maltose in S. coelicolor [12]; ngcEFG for $\mathrm{N}$-acetylglucosamine (GlcNAc) and (GlcNAc) ${ }_{2}$ in Streptomyces olivaceoviridis [13]; and bxlEFG for xylobiose in Streptomyces thermoviolaceus [14]. Interestingly, all of these operons encode subunits of $\mathrm{ABC}$ transporters, with the $E$ and $F G$ genes of these uptake systems encoding sugar-binding proteins (SBPs) (CebE, MalE, NgcE and BxlE) and two putative integral membrane proteins (CebFG, MalFG, NgcFG and BxlFG), respectively [15]. Deficient in aerial mycelium and spore formation (DasRABC) was first identified in S. griseus as an ATP-binding cassette transport system involved in regulation of morphological differentiation in response to glucose and is one of the best studied ABC transporters in Streptomycetes [16]. Our previous study demonstrated that ste34 in Streptomyces sp. 139 are homologous to the membrane spanning protein encoding genes das $B C$ [17]. The disruption of ste34 resulted in a mutant strain with dramatically decreased production of Ebosin [17]. Meanwhile, the effect of Ste2, which has high homology to DasA from S. coelicolor and S. griseus, remains unclear. Here, we demonstrate that the sugar binding protein Ste2 controls nutrient uptake, exopolysaccharide yields, morphological differentiation, sensitivity to oxidative stress and microbial morphology of Streptomyces sp. 139.

\section{Results}

\section{Homology analysis of Ste2}

Whole genome sequence of Streptomyces sp. 139 is available [18]. Amino acid alignment of Ste2 with DasA has been done with Clustal Omega Software (https://www. ebi.ac.uk/Tools $/ \mathrm{msa} /$ clustalo/) and is shown in Supplementary Fig. 1. Ste2 shows $84 \%$ identity and $91 \%$ similarity to the sugar binding protein DasA of Streptomyces coelicolor A3 (2) [19, 20], 34\% identity and 49\% similarity to DasA of Streptomyces griseus [16] (Supp. Figure 1A). Homology of Ste34 to DasBC has been published in our previous research [17], and the alignment is shown in Supp. Figure 1B-C. Ste3 shows 89\% identity and 94\% similarity to integral membrane protein DasB of Streptomyces coelicolor A3 (2) [19, 20], 35\% identity and 58\% similarity to DasB of Streptomyces griseus [21] (Supp. Figure 1B). Ste4 shows $87 \%$ identity and $94 \%$ similarity to integral membrane protein DasC of Streptomyces coelicolor A3 (2) [19, 20], 41\% identity and 63\% similarity to DasC of Streptomyces griseus [21] (Supp. Figure 1C). We hypothesize that ste234, adjacent to GntR family regulator ste1, encodes an ATP-binding cassette (ABC)-type transporter for carbohydrate uptake as DasABC of Streptomyces coelicolor A3 (2) and Streptomyces griseus.

\section{Strain construction and validation}

To elucidate the function of Ste2 in the biosynthesis of Ebosin, the ste2 deletion strain (strain D2) was constructed using a double cross-over gene-replacement strategy. A number of colonies $\left(\mathrm{Km}^{\mathrm{r}} \mathrm{Am}^{\mathrm{s}}\right)$ were selected randomly and their genomic DNAs were isolated and confirmed by Southern hybridization. As shown in Fig. 1A, ste1-4 is located within two BamHI cut sites, giving a $5.8 \mathrm{~kb}$ fragment following BamHI digestions. When ste 2 was replaced with the $K m$ fragment, this $B a m H I$ fragment was $6.3 \mathrm{~kb}$ (Fig. 1A). As shown in Fig. 1B, a distinctive hybridization band of $6.3 \mathrm{~kb}$ was detected in the ste2-deleted mutant strain, designated as strain D2 (Fig. 1B, line 2), and a band of $5.8 \mathrm{~kb}$ was obtained for wild type strain (Fig. 1B, line 1). To study whether the effects of ste 2 deletion can be reversed by the complementation of ste2, the complementary strain was constructed as described in the method section. Briefly, fragment erm $\mathrm{E}^{*}$ and ste 2 were ligated together and inserted into the BamHI-HindIII-cut pKC1139 vector to yield pKC2C. After being propagated in E. coli ET12567, $\mathrm{pKC} 2 \mathrm{C}$ was isolated and transformed into the protoplasts of strain D2. 10 transformants $\left(\mathrm{Am}^{\mathrm{r}} \mathrm{Km}^{\mathrm{r}}\right)$ were obtained and the existence of $\mathrm{pKC} 2 \mathrm{C}$ was confirmed by restriction digestion pattern (not shown). The complementary strain was designated as strain $\mathrm{C} 2$.

\section{Disruption of ste2 dramatically enhances Ebosin production in Streptomyces sp. 139}

The fermentation supernatant at $96 \mathrm{~h}$ for Streptomyces sp. 139, Strain D2 and Strain C2 were harvested by centrifugation, and then analyzed by ELISA for the determination of its antagonist rate for IL-1R (Fig. 2A), as well as quantified for the total yield of Ebosin (Fig. 2B), respectively. The disruption of ste 2 resulted in a more than $50 \%$ increase in the supernatant's antagonist rate for IL-1R, and the complemented strain has about the same rate as the native strain. Strain D2 has an around twofold increase in its Ebosin production, while the complemented strain $\mathrm{C} 2$ has similar production level as the native strain.

The $\mathrm{pH}$ value of each sample was also analyzed. As the incubation time prolonged, the $\mathrm{pH}$ value of culture supernatant gradually increased from around 6.7 to 8.2. $\mathrm{pH}$ value of culture supernatant between Streptomyces 


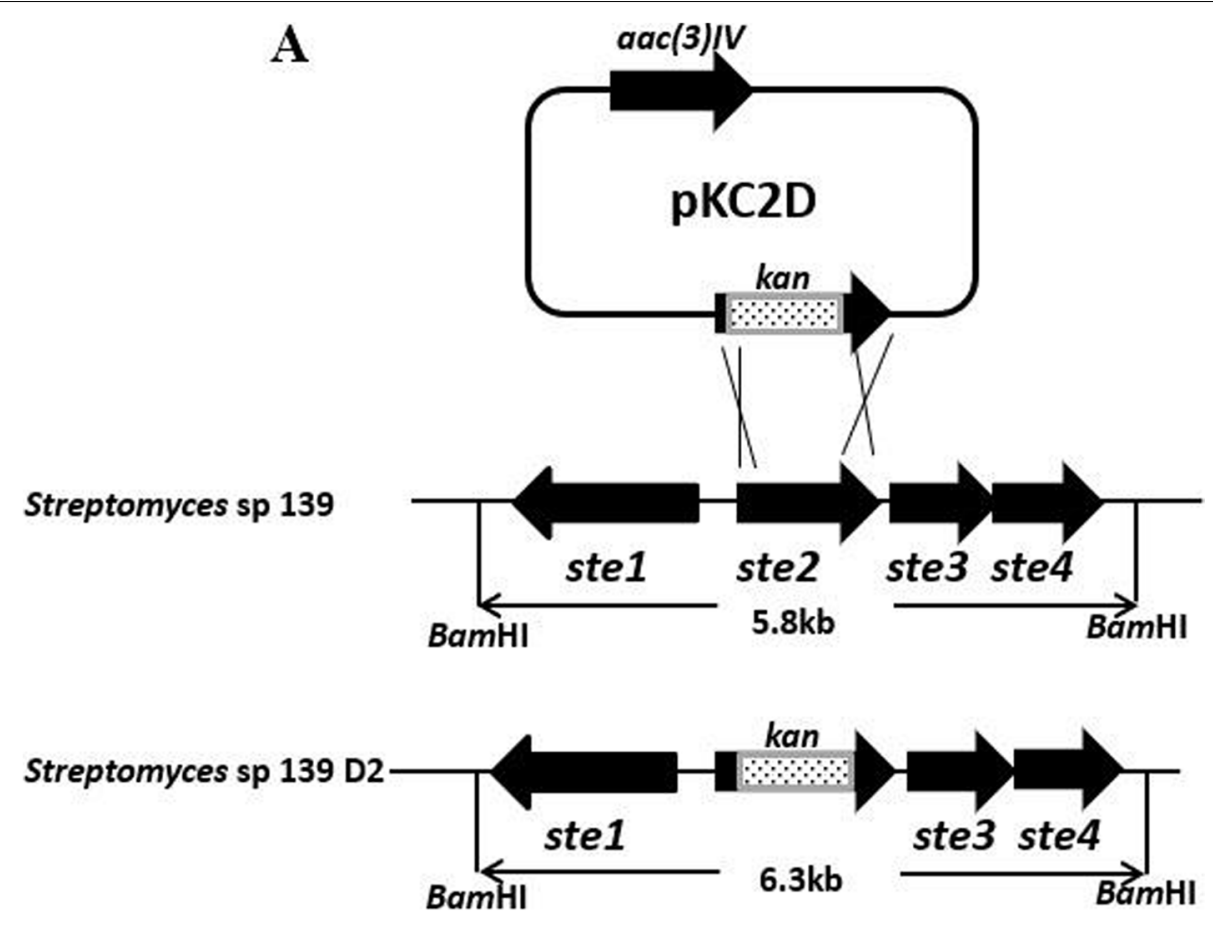

B

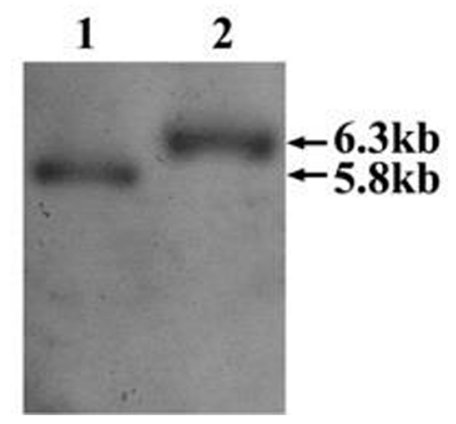

Fig. 1 Southern blotting analyses of the wild-type Streptomyces sp. 139 and Strain D2. A Representative of the construction of the ste2 disruption strain D2. B (Line 1) Streptomyces sp. 139 chromosome DNA digested with BamHI and Hindlll, (Line 2) Strain D2 chromosome DNA digested with $\mathrm{BamHI}$, a DIG-labeled F1 as the hybridization probe. kan: kanamycin resistance gene fragment

sp. 139, strain D2 and strain C2 did not show significant difference (Fig. 2C).

The wet mycelium weight of Streptomyces sp. 139, strain D2 and strain C2 at each time point were shown in Fig. 2D. Mycelium density reached maximum during $48 \mathrm{~h}$ to $72 \mathrm{~h}$ incubation period, while mycelium density of Streptomyces sp. 139 was higher than strain D2 and strain C2.
Expression of genes within Ebosin biosynthetic gene cluster are significantly upregulated in D2 strain

A RT-qPCR experiment was performed to further confirm whether genes within Ebosin biosynthetic gene cluster were regulated at certain time points (Fig. 3). The genes encoding galactosyltransferase (ste5) [5], chain length determinants (Wzz) (ste8) [5], and $\alpha$-D-glucose-1phosphate cytidylyltransferase (ste17) [22], respectively, 

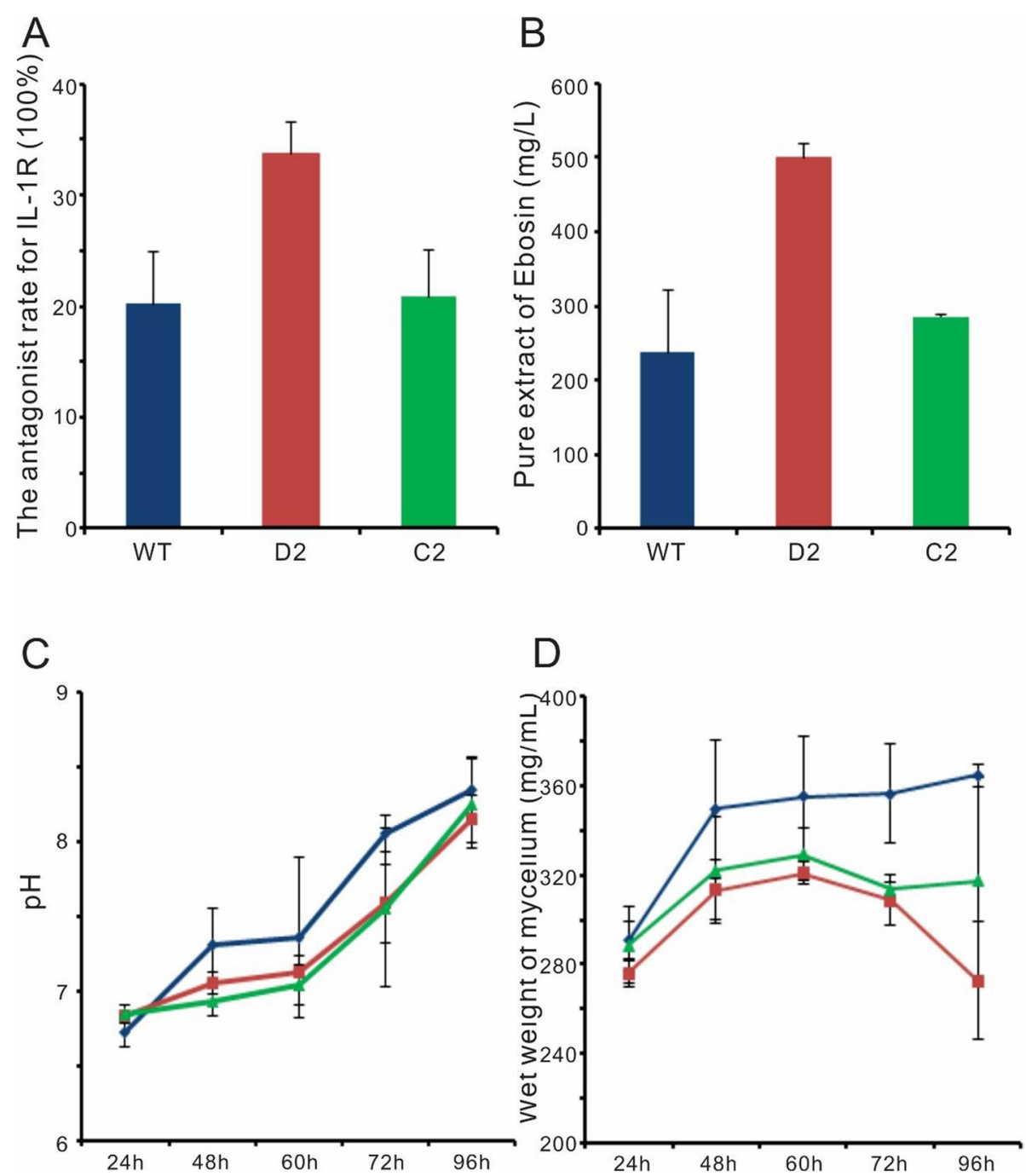

Fig. 2 Analysis of fermentation of wild type Streptomyces sp. 139, mutant strain D2 and C2. Blue: wild-type strain; red: strain D2; green: strain C2. A The competitive binding activities of the fermentation supernatant with IL-1 for IL-1R. Samples were collected at $96 \mathrm{~h}$. B The production of Ebosin at $96 \mathrm{~h}$ from Streptomyces sp. 139, Strain D2 and Strain C2. C pH of the fermentation process at different times. D Wet weight of mycelium of fermentation broth sampled at different time points

were chosen for this experiment. As shown in Fig. 3, ste5, ste8, and ste17 were upregulated for at least 3-fold in D2 strain at $24 \mathrm{~h}$, all of which are statistically significant $(p<0.05)$. At $48 \mathrm{~h}$, ste 5 was upregulated for around twofold in D2 strain $(p<0.05)$, ste8 was upregulated for about threefold in D2 strain $(p<0.05)$, while the upregulation of ste17 was not that significant $(p>0.05)$. At $96 \mathrm{~h}$, there was not a significant difference in the transcription of the three genes in all strains $(p>0.05)$. The complemented strain has similar transcription level as wild-type strain at all time points $(p>0.05)$. As a conclusion, the deletion of ste 2 resulted in the upregulated transcription of ste5, ste8, and ste17, especially in the first $48 \mathrm{~h}$, which cooperates with the fact that the Ebosin yield is promoted in D2 strain.

\section{Strain D2 has a defect in the utilization of GIcNAc and (GICNAC)}

To investigate whether Ste2 plays a role in the uptake of aminosugars, we quantified the rate of utilization of glucose (Fig. 4A-B), GlcNAc (Fig. 4C-D) and (GlcNAc) (Fig. 4E-F) in the supernatant of the native and D2 strain which was cultured in basic media $\left(10 \mathrm{mM} \mathrm{K} \mathrm{HPO}_{4}\right.$, $10 \mathrm{mM} \mathrm{KH} \mathrm{KO}_{4}, 1 \mathrm{mM} \mathrm{CaCl}, 0.5 \mathrm{mM} \mathrm{MgCl}, 0.1 \%$ $(\mathrm{v} / \mathrm{v})$ trace element solution) supplemented with $250 \mu \mathrm{M}$ of glucose, GlcNAc and (GlcNAc) ${ }_{2}$, respectively. Both 


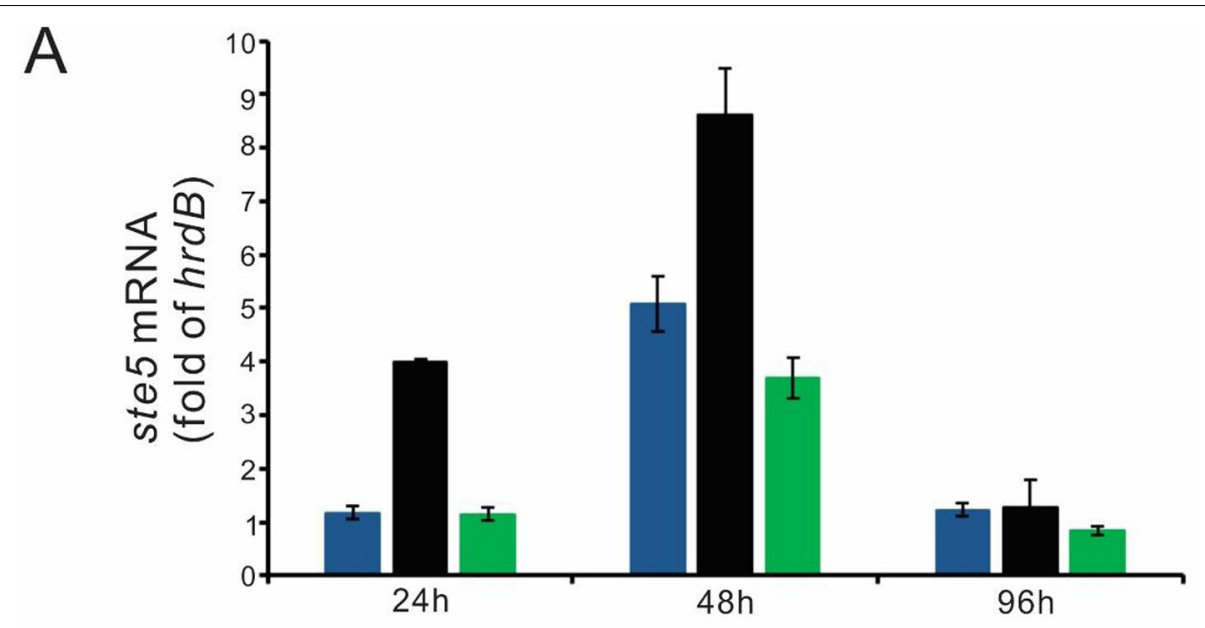

B

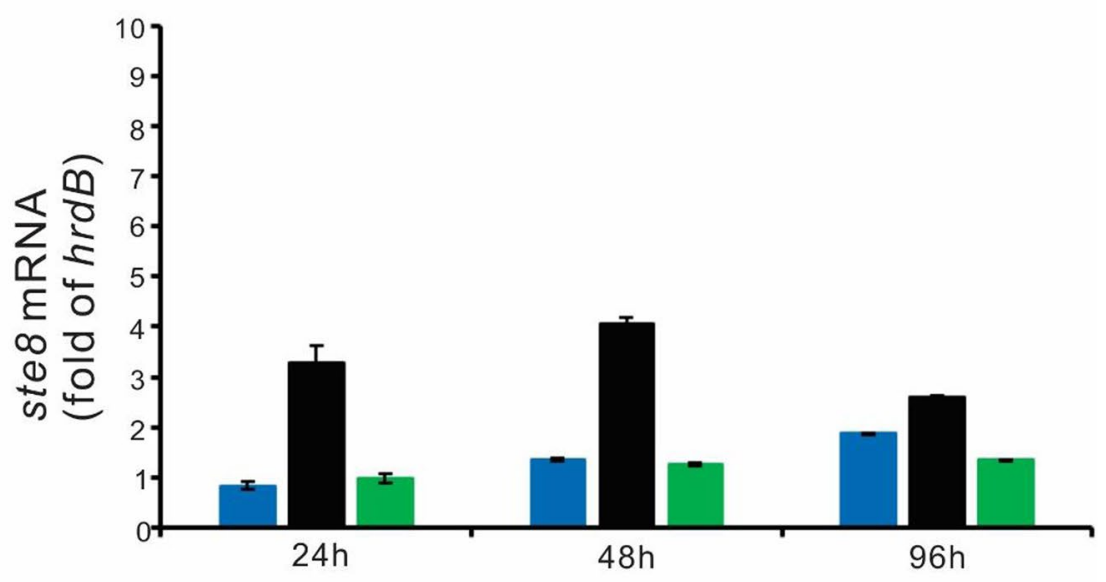

C

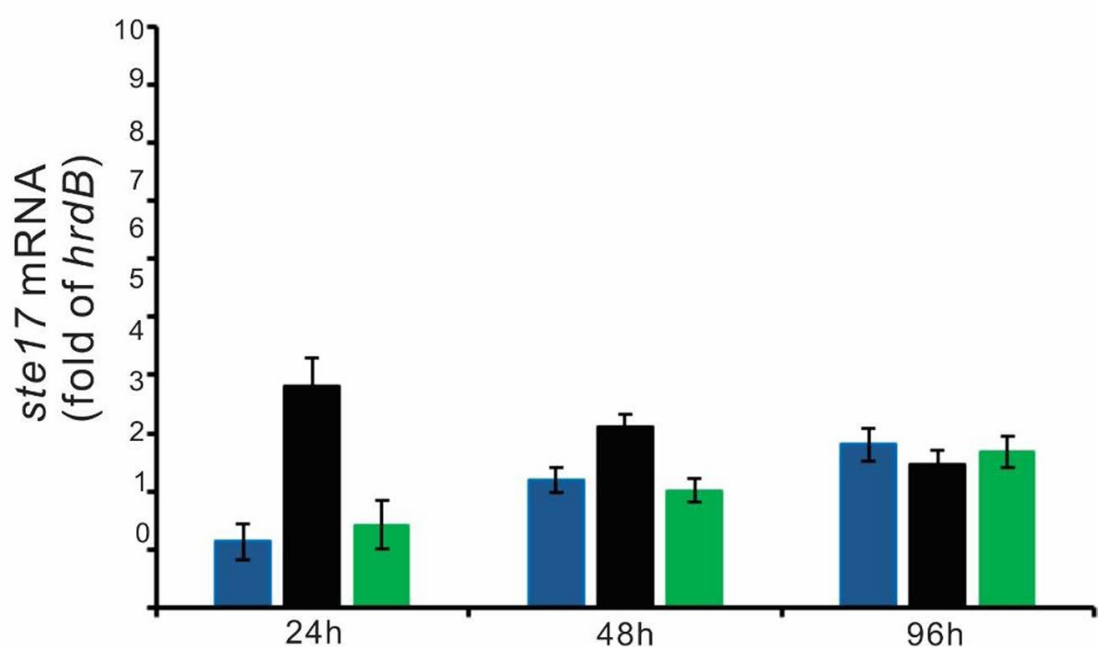

Fig. 3 Quantification of the transcription level of ste5 (A), ste8 (B), and ste17 (C) in Streptomyces sp. 139 wild-type, D2 and C2 strain. Strains were allowed to grow for $24 \mathrm{~h}, 48 \mathrm{~h}$, and $96 \mathrm{~h}$ before analysis. The transcription level of ste5, ste8, and ste 17 was normalized to the transcription level of hrdB, respectively. Blue: wild-type strain; black: strain D2; green: strain C2. Experiments were done in triplicate 

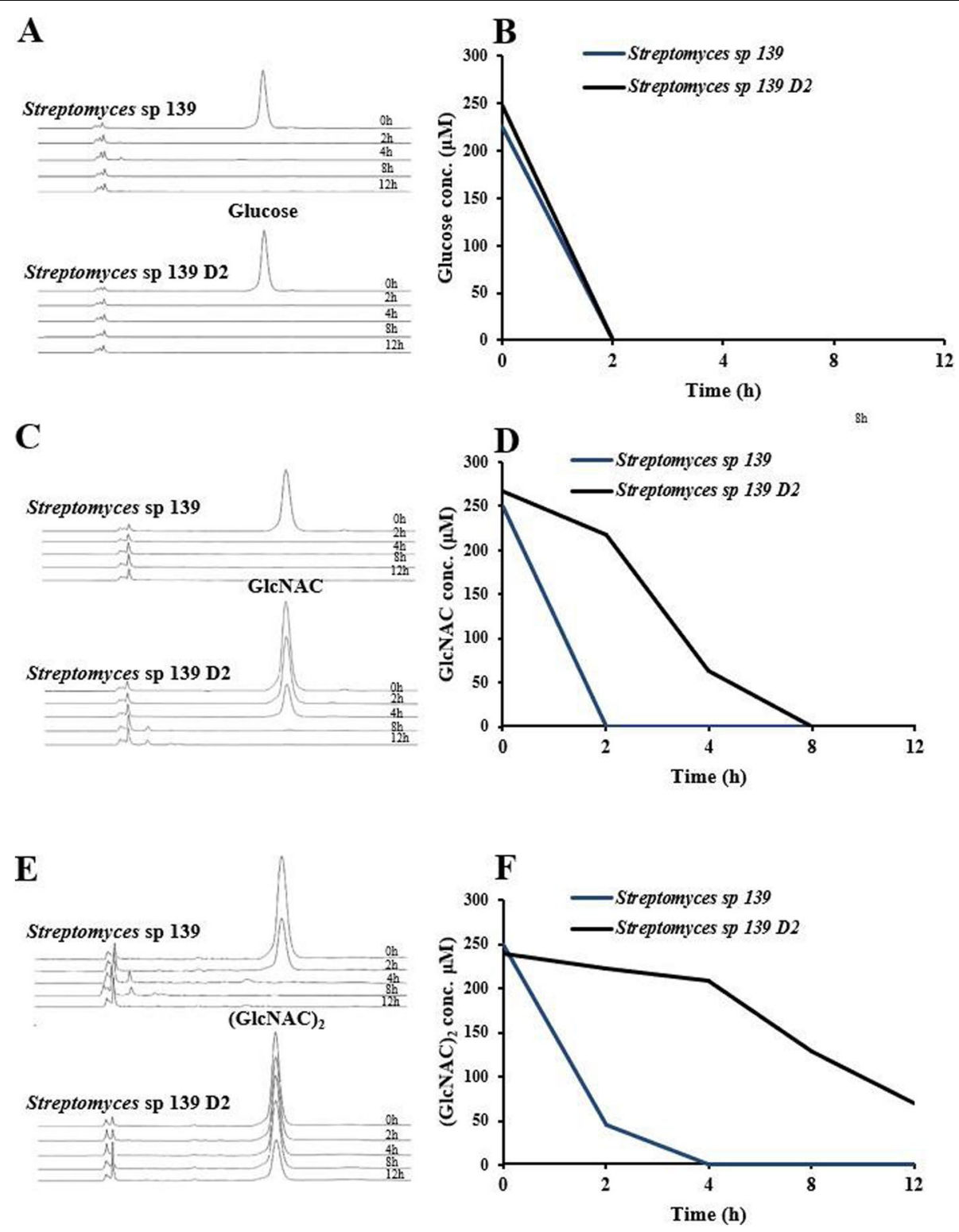

Fig. 4 Quantification of the utilization of glucose (A\&B), GlcNAc (C\&D), and (GlcNAc) 2 (E\&F) in Streptomyces sp. 139 and mutant strain D2. S139 native and D2 strain were cultured in basic media (10 $\mathrm{mM} \mathrm{K}_{2} \mathrm{HPO}_{4}, 10 \mathrm{mM} \mathrm{KH}_{2} \mathrm{PO}_{4}, 1 \mathrm{mM} \mathrm{CaCl}_{2}, 0.5 \mathrm{mM} \mathrm{MgCl}, 0.1 \%$ ( $\mathrm{v} / \mathrm{v}$ ) trace element solution) supplemented with $250 \mu \mathrm{M}$ of glucose (A\&B), GlcNAc (C\&D) and (GlcNAc) $(E \& F)$, respectively. Bacterial culture samples were taken at $0 \mathrm{~h}, 2 \mathrm{~h}, 4 \mathrm{~h}$, $8 \mathrm{~h}$, and $12 \mathrm{~h}$, and were analyzed for the concentration of glucose, GlcNAc and (GICNAc) 2 , respectively

strains absorbed all supplemented glucose within the first two hours. However, the disruption of ste2 significantly decreased the uptake of GlcNAc and (GlcNAc) $)_{2}$. Wildtype 139 strain utilized all supplemented GlcNAc within the first $2 \mathrm{~h}$, while the D2 strain utilized only $20 \%$ supplemented GlcNAc during the same period of time, and all supplemented GlcNAc at $8 \mathrm{~h}$. As for $(\mathrm{GlcNAc})_{2}$, wildtype strain utilized $80 \%$ within $2 \mathrm{~h}$ and nearly all supplemented (GlcNAc) $)_{2}$ within $4 \mathrm{~h}$. The D2 strain barely utilized any $(\mathrm{GlcNAc})_{2}$ within the first $4 \mathrm{~h}$, around $50 \%$ until $8 \mathrm{~h}$, while around $70 \%$ until $12 \mathrm{~h}$. The results suggest that Ste2 plays an important role in the utilization of GlcNAc and (GlcNAc) ${ }_{2}$ in Streptomyces sp. 139.

\section{ste2 null mutant has a highly aberrant phenotype}

A closer inspection of the native and D2 strain with a cryoscanning electron microscope is shown in Fig. 5. On the minimum medium supplemented with glucose or R2YE agar medium, Streptomyces sp. 139 (WT) produced abundant and wild-type spores (Fig. 5A, B). In contrast, Strain 


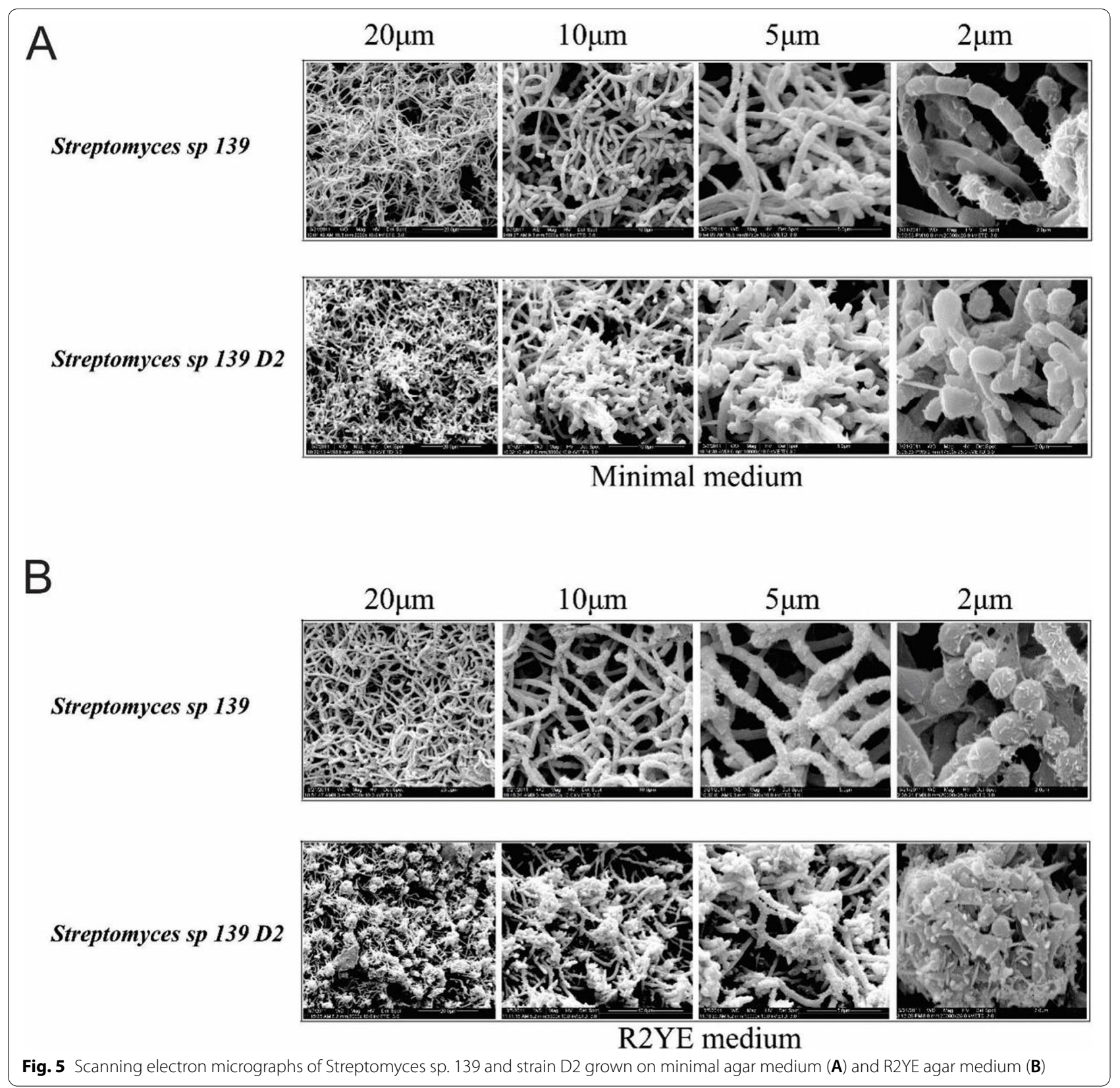

D2 failed to produce normal aerial hyphae and spores on minimum medium supplemented with glucose (Fig. 5A). Excitingly, the ste 2 mutant on R2YE agar medium had highly aberrantly shaped spores, which produced spore heaps at a high frequency (Fig. 5B). To our knowledge, such a phenotype has not been established before in any Streptomyces mutant.
Global transcriptional changes in Streptomyces sp. 139 D2 mutant

Transcriptome analysis was done in triplicate for both the wild type strain and ste 2 mutant strain. Using a cut-off of 2.0-fold difference between the wild-type and D2 mutant, 2476 genes were identified as differentially expressed. As shown in Fig. 6A, 1118 genes were upregulated and 


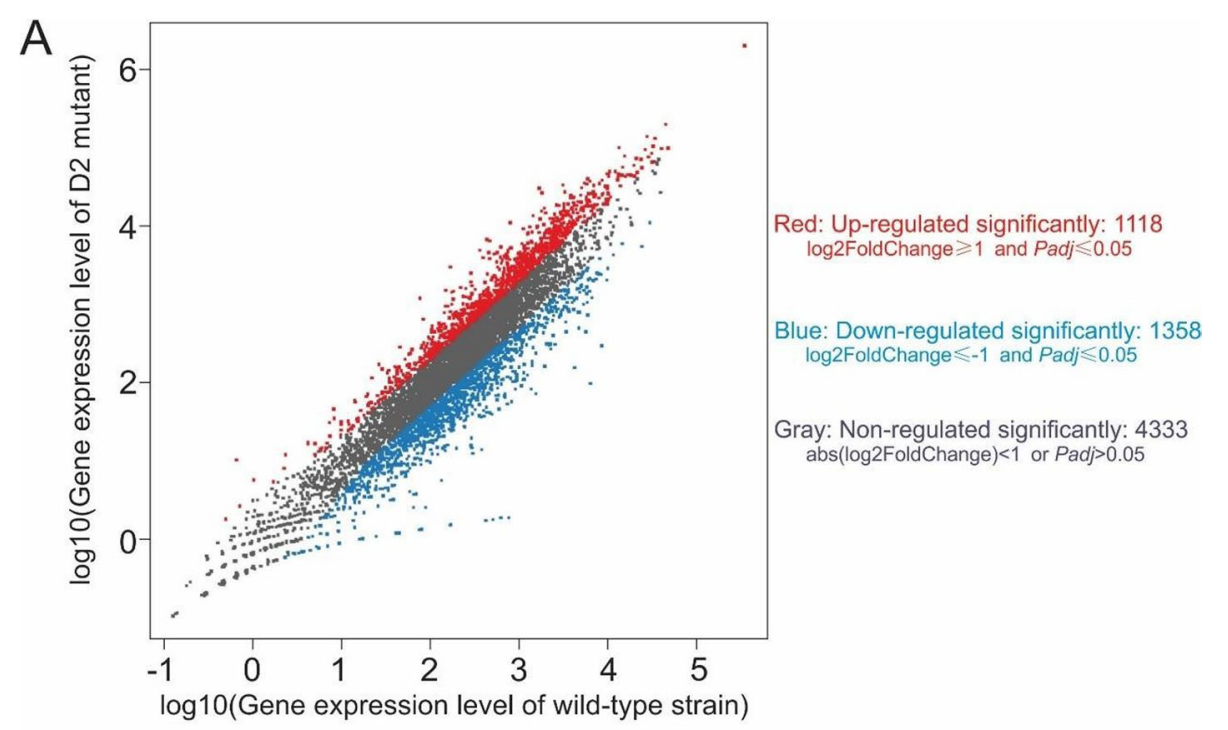

B

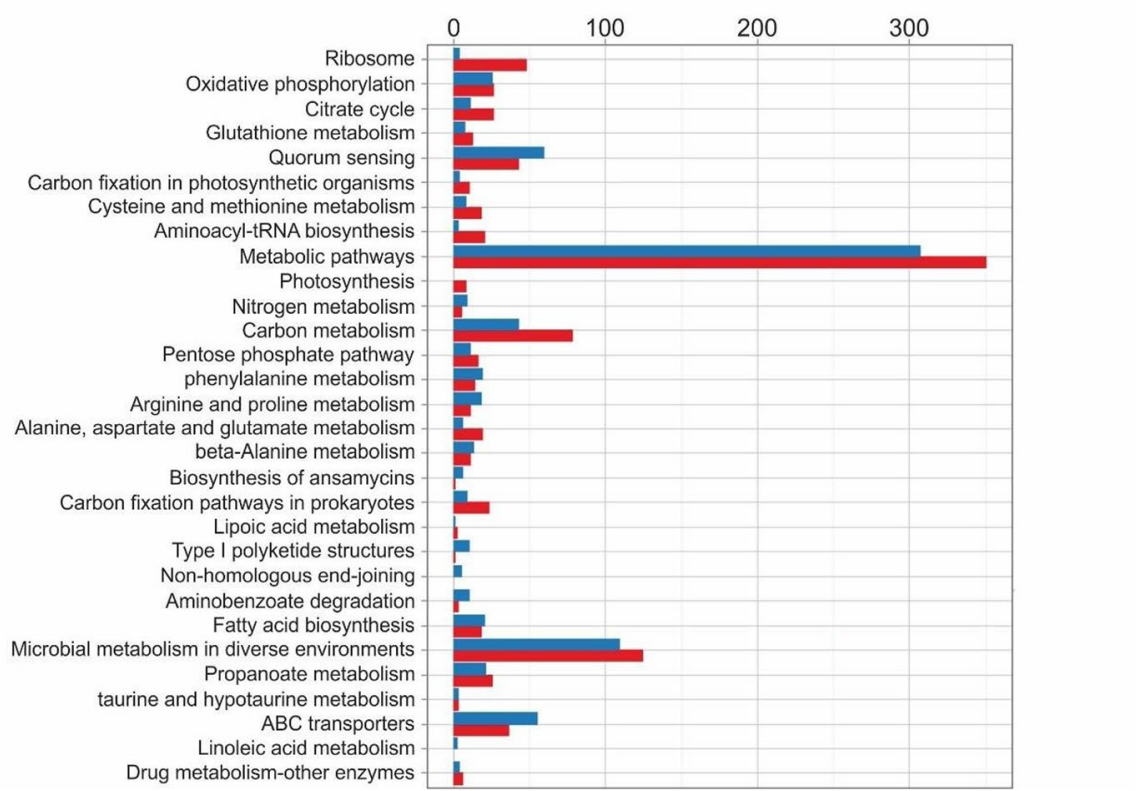

Fig. 6 Functional categories and enrichment analysis of the DEGs. A Scatter plot of log10 gene expression levels before and after the deletion of ste2. B DEGs number of the most enriched pathway. Blue: down-regulated; Red: up-regulated

1358 genes were downregulated for more than 2.0-fold in D2 mutant when compared with wild-type strain, and those changes are statistically significant (Adjusted $\mathrm{P}$ value $<=0.001[23]) .4333$ genes were not regulated in a statistical significantly manner. According to the National Center for Biotechnology Information (NCBI) S139 genome annotation, gene-annotation enrichment and functional annotation clustering analysis of differentially expressed genes (DEGs) were conducted [23]. As shown in Fig. 6B, the DEGs were enriched in thirty significantly changed terms in Kyoto Encyclopedia of Genes and Genomes (KEGG) pathways. According to the KEGG pathways definition, most of the genes being significantly regulated are involved in metabolic pathways, following which are microbial metabolism in diverse environments, quorum sensing, carbon metabolism, $\mathrm{ABC}$ transporters, etc. (Fig. 6B).

According to the RNA sequencing analysis provided by Beijing Genomics Institute (Table S1), we found that 111 genes have a higher than eight-folds difference in their expression level in the ste 2 mutant strain compared with wild type strain. Within the 111 genes, 86 genes were down-regulated, while 25 genes were up-regulated. Most of the genes have a close relationship with metabolic 
pathways, microbial metabolism in diverse environments, quorum sensing, as well as carbon and nitrogen metabolism. It is clear that in ste 2 mutant strain, some genes with their expression levels significantly differed from wild strain are involved in carbon/nitrogen fixation and cellular response to oxidative stress. For example, a gene encoding a carbohydrate $A B C$ transporter substrate-binding protein has a 15.7 -fold increase in its expression level in ste 2 mutant strain. The protein is a periplasmic component within an ABC-type glycerol3-phosphate transport system and is involved in carbohydrate transport and metabolism. A gene encoding an MBL fold metallo-hydrolase has an 18-fold increase in its expression level in ste 2 mutant strain. The protein is a $\mathrm{L}$-ascorbate metabolism protein and is involved in carbohydrate transport and metabolism.

A selected collection of genes of interest have been summarized in Table 1. Apart from genes regulating carbon metabolism, two genes encoding methionine adenosyltransferase and glutamate-ammonia ligase have been upregulated for around three- and seven-folds, respectively. It suggests that the amino acid metabolism in ste2 disruption strain is also promoted. Excitingly, two genes encoding putative $\mathrm{N}, \mathrm{N}^{\prime}$-diacetylchitobiose transport system substrate-binding proteins have a 6.47 -fold and 2.17-fold decrease in their expression levels in ste 2 mutant strain, respectively, which corroborates with the decreased uptake of GlcNAc and (GlcNAc) $)_{2}$ in the D2 strain. Interestingly, a gene encoding a cyclic-di-GMPbinding protein has a 3.7 -fold increase in the D2 strain. It has been previously reported that the bacterial EPSs are regulated for c-di-GMP, and c-di-GMP also plays a key role in the utilization of nitrogen source, the biosynthesis of multiple nucleoside precursors, and response to oxygen, nitric oxide, and a variety of other environmental challenges [24, 25]. However, c-di-GMP binding proteins are highly diverse, and identification of them remains a difficult and incomplete task [26], thus the increase in the expression level of the c-di-GMP-binding protein in the D2 strain needs future investigation.

The differed morphology of wild-type and D2 strain might be attributed to the differed expression of three rod shape-determining protein $\mathrm{MreB}$ and related proteins, in which two genes are down-regulated, while one

Table 1 Selected genes being significantly up- or down-regulated in the ste2 disruption strain D2. The function, KEGG orthology, and a result of BLAST are shown for each gene, respectively

\begin{tabular}{|c|c|c|c|c|}
\hline Function & Gene ID & D2 to WT Ratio & KEGG Orthology & Blast nr \\
\hline \multirow[t]{2}{*}{ Carbohydrate metabolism } & S139GL004816 & 15.74661713 & $\begin{array}{l}\text { alpha-glucoside transport system } \\
\text { substrate-binding protein }\end{array}$ & $\begin{array}{l}\text { carbohydrate } \mathrm{ABC} \text { transporter substrate- } \\
\text { binding protein } \\
\text { [Streptomyces sp. } \mathrm{CNH} 189]\end{array}$ \\
\hline & S139GL004057 & 18.01236617 & peptidoglycan DL-endopeptidase CwlO & $\begin{array}{l}\text { MBL fold metallo-hydrolase [Streptomyces } \\
\text { sp. CNH189] }\end{array}$ \\
\hline \multirow[t]{2}{*}{ Amino acid metabolism } & S139GL002102 & 2.958184062 & S-adenosylmethionine synthetase & $\begin{array}{l}\text { methionine adenosyltransferase [Strepto- } \\
\text { myces sp. CNH189] }\end{array}$ \\
\hline & S139GL005081 & 6.721092236 & glutamine synthetase & glutamate-ammonia ligase [Streptomyces] \\
\hline \multirow[t]{2}{*}{ Membrane transport } & S139GL002390 & 0.154636472 & $\begin{array}{l}\mathrm{N}, \mathrm{N}^{\prime} \text {-diacetylchitobiose transport system } \\
\text { substrate-binding protein }\end{array}$ & $\begin{array}{l}\text { putative sugar transporter sugar-binding } \\
\text { protein [Streptomyces sp. 139] }\end{array}$ \\
\hline & S139GL002391 & 0.461712269 & $\begin{array}{l}\mathrm{N}, \mathrm{N}^{\prime} \text {-diacetylchitobiose transport system } \\
\text { permease protein }\end{array}$ & $\begin{array}{l}\text { putative sugar transporter integral mem- } \\
\text { brane protein } \\
\text { [Streptomyces sp. 139] }\end{array}$ \\
\hline \multirow[t]{4}{*}{ Response to oxidative stress } & S139GL004328 & 0.226084044 & catalase-peroxidase & $\begin{array}{l}\text { catalase/peroxidase HPI [Streptomyces sp. } \\
\text { CB02400] }\end{array}$ \\
\hline & S139GL003847 & 0.196900796 & $\begin{array}{l}\text { ATP-binding cassette, subfamily C, bacte- } \\
\text { rial CydCD }\end{array}$ & $\begin{array}{l}\text { ABC transporter ATP-binding protein } \\
\text { [Actinobacteria] }\end{array}$ \\
\hline & S139GL000959 & 5.552515326 & $\begin{array}{l}\text { peroxiredoxin [alkyl hydroperoxide } \\
\text { reductase subunit } C \text { ] }\end{array}$ & peroxiredoxin [Streptomyces sp. CNH189] \\
\hline & S139GL001510 & 4.306959158 & aldehyde dehydrogenase [NAD +] & $\begin{array}{l}\text { aldehyde dehydrogenase [Streptomyces sp. } \\
\text { CNH189] }\end{array}$ \\
\hline $\begin{array}{l}\text { Metabolism/ } \\
\text { regulation }\end{array}$ & S139GL000617 & 3.71384308 & cyclic-di-GMP-binding protein & $\begin{array}{l}\text { DUF520 domain-containing protein } \\
\text { [Streptomyces] }\end{array}$ \\
\hline \multirow[t]{3}{*}{ Cell morphology } & S139GL003161 & 0.45401102 & $\begin{array}{l}\text { rod shape-determining protein MreB } \\
\text { and related proteins }\end{array}$ & $\begin{array}{l}\text { hypothetical protein [Streptomyces sp. } \\
\text { CNH189] }\end{array}$ \\
\hline & S139GL005336 & 0.179128887 & $\begin{array}{l}\text { rod shape-determining protein MreB } \\
\text { and related proteins }\end{array}$ & $\begin{array}{l}\text { rod shape-determining protein [Actino- } \\
\text { bacteria] }\end{array}$ \\
\hline & S139GL005480 & 2.244936284 & $\begin{array}{l}\text { rod shape-determining protein MreB } \\
\text { and related proteins }\end{array}$ & $\begin{array}{l}\text { rod shape-determining protein [Strepto- } \\
\text { myces] }\end{array}$ \\
\hline
\end{tabular}


gene is up-regulated. MreB, the cell shape-determining bacterial actin homologue, has been demonstrated to be required for the maintenance of a rod-shaped cell and formation of spirals that traverse along the longitudinal axis of Bacillus subtilis and E. coli cells; MreB filaments also function as a cytoskeleton, serving as an organizer or tracking device for the cell wall morphogenesis in Caulobacter crescentus [27]. In S. coelicolor, MreB has been demonstrated to localize underneath the internal spore wall but not in vegetative mycelium, and has been suggested to function in the formation of environmentally stable spores [28]. The regulation of cellular shape might be a complicated process in Streptomyces sp. 139 strain and future work will be required.

Genes involved in responding to oxidative stress are regulated in a more complicated manner. A gene encoding a catalase-peroxidase (S139GL004328) is down-regulated for more than four-folds in D2 strain. A homologue of the catalase-peroxidase KatG in E. coli has been demonstrated to have both catalase and broad-spectrum peroxidase activity, plus NADH oxidase, INH lyase and isonicotinoyl-NAD synthase activity, in which INH lyase and isonicotinoyl-NAD synthase are responsible for the activation of isoniazid as an anti-tubercular drug [29]. It suggests the D2 strain will be more sensitive to oxidative stress than wild-type strain. A gene encoding a homologue to the bacterial heterodimeric $\mathrm{ABC}$ transporter CydCD is down-regulated for more than fivefolds in D2 strain. In E. coli, CydCD is required for the biogenesis of both cytochrome $b d$-type quinol oxidases and periplasmic cytochromes. CydDC could also act as a thiol transporter [30]. Thus the disruption of ste 2 may also render the strain to be more sensitive to oxidative stress. In the meantime, genes encoding homologues of peroxiredoxin and aldehyde dehydrogenase in Streptomyces sp. CNH189 are upregulated for 4.3- and 5.6-folds in D2 strain, suggesting that the survival rate of D2 strain may be increased under oxidative stress. For more information, a full list of genes whose expression changed significantly is available in Table S1.

To summarize, we hypothesize that the deletion of ste 2 enhances the strain's ability to metabolize carbohydrates and amino acids, to sense and deal with oxidative stress from hydrogen peroxide and aldehydes in the outside environment; in the meantime, the deletion of ste 2 decreases the strain's ability to uptake aminosugars like $\mathrm{N}, \mathrm{N}^{\prime}$-diacetylchitobiose. Morphology of the strain is also affected by differed expression of multiple rod shapedetermining proteins.

\section{Strain D2 is more sensitive to hydrogen peroxide than the wild-type strain and strain C2}

Global transcriptional changes in Streptomyces sp. 139 D2 mutant revealed that the disruption of ste2 may render the strain to be more sensitive to oxidative stress. We decided to test whether hydrogen peroxide has a differed effect in the growth of wild-type and D2 strain, as hydrogen peroxide is a natural source of oxidative stress. Wildtype strain and strain $\mathrm{C} 2$ are less sensitive to hydrogen peroxide compared with strain D2. The MIC of hydrogen

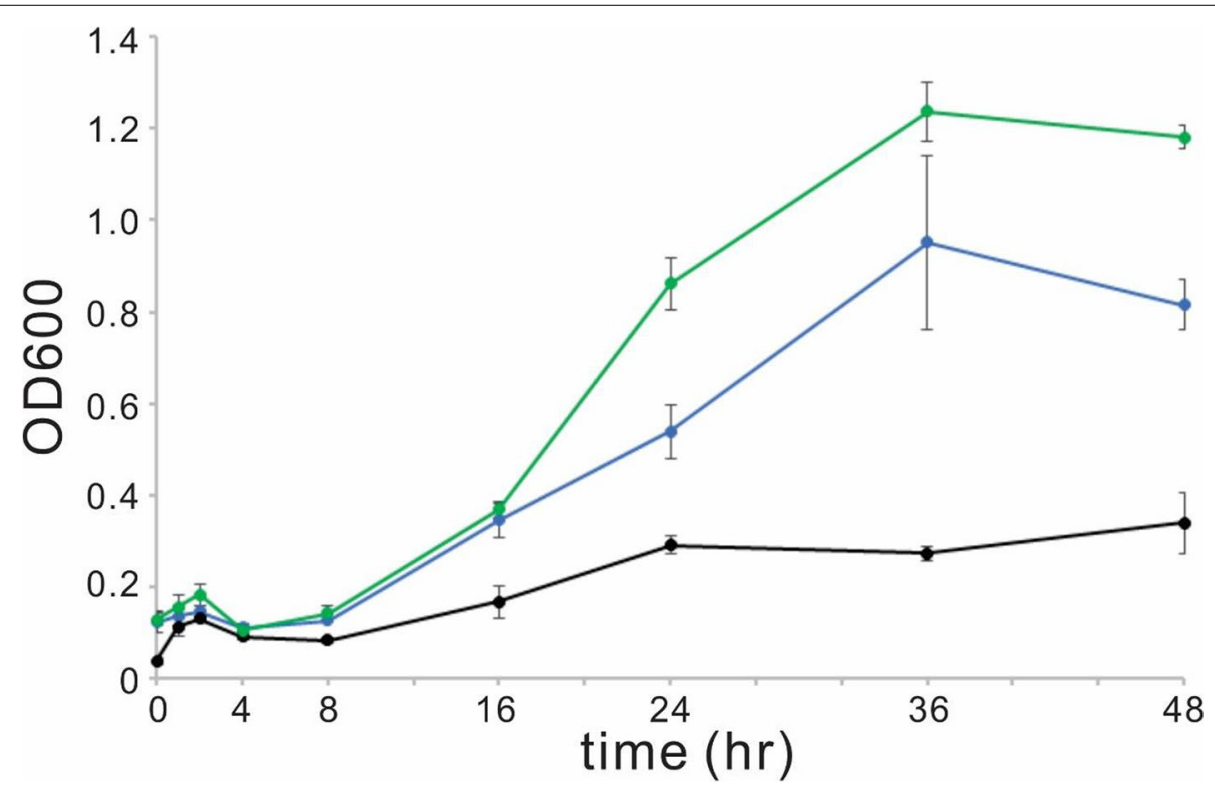

Fig. 7 Bacterial growth under the treatment of $0.1 \%$ hydrogen peroxide. Samples were taken and analyzed for OD600 at 0, 1, 2, 4, 8, 16, 24, 36, and 48 h. Black line: strain D2; blue line: wild-type strain; green line: strain C2. Experiments were done in triplicate 
peroxide against wild-type strain and strain C2 is $1 \%$, while is $0.25 \%$ against strain D2. Thus Ste2 might play a role in protecting the strain from oxidative stress, which corroborates with the RNA seq analysis. To further investigate the effect of hydrogen peroxide on the growth of the three strains, we performed a strain growth test (Fig. 7). At a selected sub-MIC concentration of hydrogen peroxide $(0.1 \%)$, the growth of strain D2 is much slower compared with both wild-type and strain C2. At $36 \mathrm{~h}$ post exposure, the OD600 of strain D2 is at around 0.3 , while are at around 0.9 and 1.2 of wild-type strain and strain $\mathrm{C} 2$, and the difference is statistical significant $(p<0.05)$. Similar trend was presented at $48 \mathrm{~h}$ post exposure, in which the difference of OD600 between strain D2 and WT/strain C2 is statistical significant $(p<0.05)$. We concluded that Ste2 has a protective role against oxidative stress resulted from hydrogen peroxide, while the detailed mechanism will require future investigation.

\section{Discussion}

Bacterial EPSs are sources of medically important substances: many microbial EPSs are found to have antiinflammation, anti-tumor, anti-aging and anti-rheumatic properties. They are synthesized via biosynthetic enzymes, being secreted into the surrounding environment, and are often important for the biofilm formation and pathogenicity [31]. As for the function of EPSs to their producing organisms, the regulation of oxidative stress has been linked to EPS synthesis in Streptococcus mutans [32]. The deletion of the diadenylate cyclase CdaA encoding gene causes decreased c-di-AMP levels, increased sensitivity to hydrogen peroxide and increased production of EPSs in S. mutans [32]. The function of Streptomycetes-origin EPSs has not been well studied yet: besides from Ebosin from Streptomyces sp. 139, only a few other Streptomyces-origin EPSs have been reported, i.e., poly- $\beta-1,6-\mathrm{N}$-acetylglucosamine from Streptomyces coelicolor and Streptomyces lividans possibly participates in the attachment of bacteria to hydrophilic surfaces [33].

DasRABC (Deficient in aerial mycelium and spore formation) was first identified in S. griseus as an ATPbinding cassette transport system involved in regulation of morphological differentiation in response to glucose [16]. Overexpression of dasA caused ectopic septation in very young substrate hyphae after only one day of growth and subsequent sporulation in response to glucose, while disruption of dasA or dasR resulted in growth as substrate mycelium [16]. In a later study, DasA has been demonstrated to act as a link between chitin utilization and morphogenesis in S. coelicolor [34]. The interruption of das $A$ resulted in an extraordinary and unique phenotype, i.e., spore chains showed extensive germination. The premature gemination could possibly be linked to the disorder of GlcNAc utilization in dasA mutants [34]. Since then, dasRABC has been extensively studied and has been linked to the Streptomycetes antibiotics biosynthesis as well as aminosugars utilization. For example, DasR is able to bind directly to the promoters of all genes encoding pathway-specific regulators of each all known antibiotics produced by $S$. coelicolor, including undecylprodigiosin, actinorhodin, cpk-cryptic polyketide and cda-calcium dependent antibiotic [35]. Moreover, DasR could sense the nutritional signals and regulate the biosynthesis of secondary metabolites $[35,36]$. The das $A B C$ gene cluster has been demonstrated to encode an $A B C$ transporter for the uptake of N, N'-Diacetylchitobiose $\left((\text { GlcNAc })_{2}\right)$ in S. coelicolor A3(2) [37]. Notably, DasA protein had the highest affinity for (GlcNAc) $)_{2}$, and the disruption of dasA resulted in a four-fold decrease in the uptake rate of (GlcNAc) $)_{2}$ GlcNAc and (GlcNAc) serve as both carbon and nitrogen sources, and are the preferred nutrient sources for Streptomycetes [38]. In this study, ste2, which is homologous to das $A$, has also been demonstrated to play an important role in the utilization of carbon/nitrogen sources including GlcNAc and (GlcNAc) ${ }_{2}$ in Streptomyces sp. 139.

Our previous study has linked Ebosin production to Ste1 (GntR family regulator DasR) and demonstrated that Ste1 serves as a transcription repressor during Ebosin biosynthesis by binding to the promoter 1 and 3 regions in the ste gene cluster with high affinity [39]. In this study, we focused on Ste2 and found Ste2 to be the negative regulator during Ebosin biosynthesis. The disruption of ste 2 results in a two-fold increase in Ebosin production. Real-time qPCR reveals that genes within Ebosin biosynthetic gene cluster are significantly upregulated in the ste2 disruption strain. RNA sequencing analysis suggests that the disruption of ste 2 possibly results in the increase of sensitivity to oxidative stress as well as the fixation of carbon and nitrogen sources, and the increased level of Ebosin being secreted would in turn help the bacterial strain to avoid cellular damage resulted from oxidative stress. Transcriptomic analysis reveals that the disruption of ste 2 results in the increase of sensitivity to oxidative stress, which is confirmed by a hydrogen peroxide sensitivity test. The ste 2 disruption strain has a defect in aminosugars uptake as well as has a different morphology compared with the native strain. A list of genes has been found to be affected by the disruption of ste2, which will be of future interest to study EPSs biosynthesis and the function of EPSs to its producing strain. To the best of our knowledge, this is the first study which links the Streptomyces-origin EPSs production to the cellular morphology, nutrient utilization, and cellular response to oxidative stress. 


\section{Conclusion}

Our findings revealed that the sugar binding protein Ste2 controls Ebosin production, aminosugars utilization, sensitivity to oxidative stress, and morphological differentiation of Streptomyces sp. 139. Our work points out the possible connection between environmental stress sensing, nutrient uptake and EPSs biosynthesis, thus will be useful for future work aimed at understanding the function of EPSs to their producing organisms and illustrating the biosynthesis of microbial EPSs that are of medical importance.

\section{Materials and methods}

Bacterial strains, plasmids, primers and growth conditions Bacterial strains, plasmids, and primers used in this work are listed in Table 2. E. coli DH5 $\alpha$ was routinely used for vectors construction. All primers were provided by Invitrogen (Beijing, China). Streptomyces sp. 139 and mutant strains were cultured in solid minimal $(10 \mathrm{mM}$
$\mathrm{K}_{2} \mathrm{HPO}_{4}, 10 \mathrm{mM} \mathrm{KH} \mathrm{PO}_{4}, 1 \mathrm{mM} \mathrm{CaCl}, 0.5 \mathrm{mM} \mathrm{MgCl} 2$ supplemented with $0.1 \% \mathrm{v} / \mathrm{v}$ trace element solution) or R2YE medium [40] plus agar $(1.5 \% \mathrm{w} / \mathrm{v})$, and were incubated at $28^{\circ} \mathrm{C}$ with shaking $(250 \mathrm{rpm})$ either in Tryptic Soy Broth (TSB, USA) supplemented with $5 \mathrm{mM} \mathrm{MgCl}_{2}$ and $0.5 \%$ glycine or in fermentation medium ( $1 \%$ glucose, $2 \%$ starch, $2 \%$ soybean extract, $0.2 \%$ tryptone, $0.2 \%$ beef extract, $0.4 \%$ yeast extract, $0.05 \% \mathrm{~K}_{2} \mathrm{HPO}_{4}, 0.3 \% \mathrm{CaCO}_{3}$, $\mathrm{pH}$ 7.3). E. coli strains were grown aerobically at $37^{\circ} \mathrm{C}$ in Luria-Bertani (LB) medium or LB solidified with agar $(1.5 \% \mathrm{w} / \mathrm{v})$ supplemented with the appropriate antibiotics $(100 \mu \mathrm{g} / \mathrm{mL}$ ampicillin, $100 \mu \mathrm{g} / \mathrm{mL}$ kanamycin or $50 \mu \mathrm{g} /$ $\mathrm{mL}$ apramycin).

\section{General DNA manipulation}

Isolation of E. coli plasmid DNA and standard recombinant DNA techniques were performed as previously described [41]. Streptomyces plasmid and genomic DNA was isolated as previously mentioned [40].

Table 2 Strains, plasmids, and primers used in this study

\begin{tabular}{|c|c|c|}
\hline Strains, plasmids, and primers & Description & Reference \\
\hline \multicolumn{3}{|l|}{ Bacterial strains } \\
\hline Streptomyces sp. 139 & Ebosin producing strain & Our lab \\
\hline Streptomyces sp. 139 D2 & ste2 knockout mutant of Streptomyces sp.139 & This study \\
\hline Streptomyces sp. 139 C2 & ste2-complemented strain & This study \\
\hline E. coli DH5a & $\mathrm{F}^{-}$recAl endA1 hsdR17 deoR thi-1 supE44 gyrA96 relA1 $\triangle($ lacZYA- $\operatorname{argF}) \cup 169 \lambda^{-}$( $(90$ dlacZ $\triangle M 15)$ & \\
\hline E. coli ET12567 & methylation-deficient E. coli; dam ${ }^{-} d \mathrm{~cm}^{-} h s d M$ & 44 \\
\hline E. coli BL21 (DE3) & $\mathrm{F}^{-}$ompThsdSB $\left(r_{B}^{-} m_{B}^{-}\right) d c m$ gal $\lambda(D E 3)$ & Novagen \\
\hline \multicolumn{3}{|l|}{ Plasmids } \\
\hline pKC1139 & Shuttle plasmid (E.coli-Streptomyces); pSG5, pBR322; aac[3]IV lacZa oriT ${ }_{\text {RK22 }} \mathrm{Am}^{\mathrm{r}}$ & 43 \\
\hline $\mathrm{pKC} 2 \mathrm{D}$ & pKC1139 derived plasmid carrying F1, F2 and $\mathrm{Km}^{r}$ fragments; $\mathrm{Km}^{r} \mathrm{Am}^{r}$ & This study \\
\hline $\mathrm{pKC} 2 \mathrm{C}$ & pKC1139 derived plasmid carrying 0.45-kb ErmE ${ }^{*}$ promoter fragment and ste2; $\mathrm{Am}^{\mathrm{r}}$ & This study \\
\hline pGEM-3Zf-ErmE $E^{*}$ & Resource of ErmE $E^{*}$ promoter; $\mathrm{Ap}^{r}$ & 45 \\
\hline pET30a & T7 promoter, His-tag; $\mathrm{Km}^{\mathrm{r}}$ & Novagen \\
\hline pET30a-ste2 & pET30a derived plasmid carrying ste2; $\mathrm{Km}^{\mathrm{r}}$ & This study \\
\hline \multicolumn{3}{|l|}{ Primers } \\
\hline $\mathrm{P} 1($ EcoRl) & CTGGAATTCGTGCCCTTGCCCTGGAT & $\mathrm{F} 1$ \\
\hline P2 (Xbal) & GCCTCTAGACTTCGCCTTGGTCTTCT & $\mathrm{F} 1$ \\
\hline P3 (Xbal) & GCATCTAGAGGCAGCCAGAAGCAGGAAC & F2 \\
\hline P4 (HindIII) & AGCAAGCTTACAGGATGGAGCGGAGG & F2 \\
\hline P5 (BamHI) & CGCGGATCCATGGGTGCGCAAGGCATT & ste2 \\
\hline P6 (HindIII) & CCCAAGCTTTTACTGCTGCTGCGCCAG & ste2 \\
\hline ste5 forward & GCTGATCCTGCTGGTGGTGC & \\
\hline ste5 reverse & CCATCGTGCGGAACTTGAGG & \\
\hline ste8 forward & CTCGGCAAGCTCAGCCAGAC & \\
\hline ste8 reverse & CGAGCAGCAGGAACAGCACC & \\
\hline ste17 forward & CTGGACGGCGACGAGAT & \\
\hline ste17 reverse & CGACGCAGTGGAACGAG & \\
\hline hrdB forward & TGGTCGAGGTCATCAACAAG & \\
\hline hrdB reverse & TGGACCTCGATGACCTTCTC & \\
\hline
\end{tabular}




\section{Disruption of ste2 in Streptomyces sp. 139}

Primers are listed in Table 2. Using Streptomyces sp. 139 chromosome as template, the 829-bp upstream region of ste2 (designated F1) was amplified with primers P1 and $\mathrm{P} 2$, while the 749-bp downstream region of ste2 (designated F2) was amplified with primers P3 and P4. P1 contains an EcoRI restriction site, $\mathrm{P} 2$ contains an $\mathrm{XbaI}$ restriction site, $\mathrm{P} 3$ contains an $\mathrm{XbaI}$ restriction site and P4 contains a HindIII restriction site. The PCR protocol is as following: initial denaturation at $98^{\circ} \mathrm{C}$ for $3 \mathrm{~min}$, 30 cycles of $20 \mathrm{~s}$ at $98^{\circ} \mathrm{C}, 30 \mathrm{~s}$ at $62^{\circ} \mathrm{C}, 1 \mathrm{~min}$ at $72^{\circ} \mathrm{C}$ and finally $10 \mathrm{~min}$ at $72^{\circ} \mathrm{C}$. A $1.2-\mathrm{kb}$ fragment containing the kanamycin resistance gene (designated F3) was obtained by digesting DNA of Streptomyces griseus SS-1198PR with $\mathrm{XbaI}$ [42].

After ligating the three DNA fragments (F1, F3, then $\mathrm{F} 2$ ), the resulting 3-kb fragment was inserted into the EcoRI-HindIII sites of pKC1139 [43] to create the ste2disruption vector $\mathrm{pKC} 2 \mathrm{D}$. After propagation in $E$. coli ET12567 [44], pKC2D was introduced into Streptomyces sp. 139 by polyethylene glycol (PEG)-mediated protoplast transformation [40]. Briefly, plates were incubated at $28^{\circ} \mathrm{C}$ for $20 \mathrm{~h}$, before being overlaid with soft R2YE $(0.7 \%$ agar) containing $40 \mu \mathrm{g} / \mathrm{L}$ of kanamycin. pKC2D bears a temperature-sensitive Streptomyces replication origin which is unable to replicate when temperature reaches $34^{\circ} \mathrm{C}$. The transformants were first incubated at $28^{\circ} \mathrm{C}$ for two days until pinpoint-size colonies appeared, and were shifted to $37{ }^{\circ} \mathrm{C}$ for further incubation. Mutants resulted from the double-crossover homologous recombination grew out of the original pinpoint-size colonies within a few days. The disruption of ste 2 on the chromosome was confirmed by Southern blot. For Southern blot analysis, a DIG high prime DNA labeling and detection starter kit II (Roche, USA) was used following the manufacturer's instructions. The resulting ste2 disruption mutant was designated as strain D2.

\section{Complementation of ste2 disruption strain}

Using Streptomyces sp. 139 chromosomal DNA as template, ste 2 was amplified with primers P5 and P6. Digested with EcoRI and BamHI, a 0.45-kb fragment of ermE" promoter was isolated from plasmid pGEM$3 \mathrm{zf}$-ermE $\mathrm{E}^{*}$ [45]. Fragment ermE $\mathrm{E}^{*}$ and ste 2 were ligated together and inserted into the BamHI-HindIII-cut pKC1139 vector to yield pKC2C. After being propagated in $E$. coli ET12567, pKC2C was isolated and transformed into the protoplasts of strain D2. The complementing strain was designated as strain $\mathrm{C} 2$.

\section{Isolation and activity analysis of Ebosin}

Ebosin was isolated from a total of $1 \mathrm{~L}$ of the supernatant of the fermentation culture of Streptomyces sp. 139,
Strain D2 and Strain C2 at $28{ }^{\circ} \mathrm{C}$ for $96 \mathrm{~h}$ in triplicate, as previously described [46].

An enzyme-linked immunosorbent assay (ELISA) was used to analyze the binding activity of isolated Ebosin with interleukin-1 (IL-1) for IL-1R [46].

\section{Determination of glucose, GIcNAc, and (GIcNAC) 2 concentrations.}

To investigate the responses of the cells to sugars, Streptomyces sp. 139 and its mutant strain Streptomyces sp. 139 D2 were cultivated by following a method described previously [39], with some modifications. Spores of Streptomyces sp. 139 strains formed on agar medium were inoculated into $100 \mathrm{~mL}$ TSB medium in a $500-\mathrm{mL}$ baffled Erlenmeyer flask and grown for $48 \mathrm{~h}$ at $28^{\circ} \mathrm{C}$ on a rotary shaker at $200 \mathrm{rpm}$. Mycelia were harvested by centrifugation $(3,000 \mathrm{rpm} ; 10 \mathrm{~min})$, washed with $\mathrm{MM}$ (A minimal medium (MM) $\left(10 \mathrm{mM} \mathrm{K} \mathrm{KPO}_{4}, 10 \mathrm{mM}\right.$ $\mathrm{KH}_{2} \mathrm{PO}_{4}, 1 \mathrm{mM} \mathrm{CaCl}, 0.5 \mathrm{mM} \mathrm{MgCl}$ supplemented with $0.1 \%$ ( $\mathrm{vol} / \mathrm{vol})$ trace element solution) without carbon sources, suspended in $25 \mathrm{ml} \mathrm{MM}$, and divided into several aliquots $(0.8 \mathrm{~g} / 25 \mathrm{ml})$. Each aliquot was supplemented with various carbon sources, i.e., $250 \mu \mathrm{M}$ of Glc, GlcNAc, (GlcNAc) ${ }_{2}$ (TCI, Japan). The culture was further grown at $28{ }^{\circ} \mathrm{C}$ on a rotary shaker at $200 \mathrm{rpm}$. Portions of the culture fluids were sampled periodically, centrifuged to separate the supernatants and the mycelia, and stored at $-80{ }^{\circ} \mathrm{C}$. The supernatants were subjected to measurements of sugar (Glc, GlcNAc, $(\text { GlcNAc) })_{2}$ ) concentrations, whereas the mycelia were used for total RNA preparation.

\section{RT-qPCR analysis}

Streptomyces sp. 139, mutant strain D2 and the complemented strain $\mathrm{C} 2$ were cultured at $28{ }^{\circ} \mathrm{C}$ for $48 \mathrm{~h}$ in TSB. $10 \mathrm{~mL}$ of the culture were inoculated into $50 \mathrm{~mL}$ fresh TSB and were cultured at $28{ }^{\circ} \mathrm{C}$ for $24 \mathrm{~h}, 48 \mathrm{~h}$, and $96 \mathrm{~h}$, respectively. At each time point, the mycelia of the three strains were collected by centrifugation $(3,000 \mathrm{~g} ; 10 \mathrm{~min})$ and washed with PBS $(\mathrm{NaCl} 137 \mathrm{mM}, \mathrm{KCl} 2.7 \mathrm{mM}$, $\mathrm{Na}_{2} \mathrm{HPO}_{4} 10 \mathrm{mM}, \mathrm{KH}_{2} \mathrm{PO}_{4} 2 \mathrm{mM}, \mathrm{pH}$ 7.4), respectively. Total RNA of each mycelia sample was isolated with the TRIzol System (TransGen) according to the manufacturer's instructions. Remaining DNA was removed by DNAse (TaKaRa). cDNA was synthesized with Superscript III First-Strain synthesis system kit for RT-PCR (TransGen) according to the manufacturer's instruction. Primers for each gene are listed in Table 1.50 ng cDNA was used for each qPCR reaction with FastStart Universal SYBR Green Master kit (Roche) following the manufacturer's instructions. All transcripts were normalized according to $h r d \mathrm{~B}$ (RNA polymerase principal sigma factor) transcript quantities. 


\section{Microscopy}

Surface-grown aerial hyphae and spores of Streptomyces sp.139, Strain D2 and strain C2 were examined by scanning electron microscopy (SEM) after four days of growth on minimal and R2YE agar, respectively. The agar blocks containing spores and hyphae were cut and fixed in $2.5 \%$ glutaraldehyde in $0.1 \mathrm{M}$ phosphate buffer $\mathrm{pH} 7.0$ for overnight at $4{ }^{\circ} \mathrm{C}$, washed three times in $0.1 \mathrm{M}$ phosphate, post-fixed in $1 \%$ osmium tetroxyde, 2-4 $\mathrm{h}$ in $0.1 \mathrm{M}$ phosphate, then $15-20 \mathrm{~min}$ in ethanol $30 \%, 50 \%, 70 \%, 85 \%, 95 \%$ and $100 \%$, respectively. Each specimen was rinsed, dehydrated, coated with platinum-gold and examined with a FEI QUANTA 200 scanning electron microscope [47].

\section{RNA sequencing}

Steptomyces sp. 139 and its mutant Strain D2 was cultured in $10 \mathrm{~mL}$ TSB medium at $28^{\circ} \mathrm{C}$ for $36 \mathrm{~h}$ in triplicate. The culture was inoculated 1:10 (vol/vol) into $50 \mathrm{ml}$ fresh TSB medium and incubated at $28{ }^{\circ} \mathrm{C}$ for $24 \mathrm{~h}$. After centrifugation at 5,000 rpm for $10 \mathrm{~min}$, the cell pellet was harvested, flash frozen in liquid nitrogen, and sent out for RNA extraction and RNA sequencing (Beijing Genomics Institute, Shenzhen, China). RNA sequencing data have been deposited in NCBI SRAs under the BioProject accession PRJNA647684 and can be accessed with the following link: https://www.ncbi. nlm.nih.gov/bioproject/PRJNA647684.

\section{$\mathrm{H}_{2} \mathrm{O}_{2}$ sensitivity experiments}

A minimum inhibition concentration (MIC) test of $\mathrm{H}_{2} \mathrm{O}_{2}$ against Streptomyces sp. 139 wild-type, D2 and $\mathrm{C} 2$ strain was performed in TSB according to the CLSI protocol [48]. The MIC of $\mathrm{H}_{2} \mathrm{O}_{2}$ against wild-type, D2 and $\mathrm{C} 2$ strain was $1 \%, 0.25 \%$ and $1 \%$, respectively. The effect of $\mathrm{H}_{2} \mathrm{O}_{2}$ on the growth of strains was tested at a sub-MIC concentration (0.1\%). The initial concentration of strains was adjusted to OD600 0.1. Bacterial strains were cultured at $28^{\circ} \mathrm{C}$ with shaking and their growth was monitored with an 800TS microplate reader (BioTek Instruments Inc.) at $0 \mathrm{~h}, 1 \mathrm{~h}, 2 \mathrm{~h}, 4 \mathrm{~h}$, $8 \mathrm{~h}, 16 \mathrm{~h}, 24 \mathrm{~h}, 36 \mathrm{~h}$ and $48 \mathrm{~h}$. Experiments were done at least in triplicate.

\section{Supplementary Information}

The online version contains supplementary material available at https://doi. org/10.1186/s12866-022-02472-7.

Additional file 1.

Additional file 2.
Acknowledgements

Not applicable.

\section{Authors' contributions}

$M G, G S$, and $L B$ conceived and designed the experiments. $M G, L A, M M, P L$, and $L G$ performed the experiments. MG, MM and LB analysed the data. MG, MM, and $L B$ wrote the paper. The author(s) read and approved the final manuscript.

\section{Funding}

This study was funded by National Key Research and Development Program of China (2018YFA0902000), National Natural Science Foundation of China (31870059 \& 31070086), The Drug Innovation Major Project (2018ZX0971 1001 -007-003), and Beijing Natural Science Foundation (5092020).

\section{Availability of data and materials}

All documents and additional data are available from the corresponding author upon reasonable request.

RNA sequencing data have been submitted to the Sequence Read Archive database of National Center for Biotechnology Information under the accession PRJNA647684 and can be accessed with the following link: https://www. ncbi.nlm.nih.gov/bioproject/PRJNA647684.

\section{Declarations}

Ethics approval and consent to participate

Not applicable.

\section{Consent for publication}

Not applicable.

\section{Competing interests}

The authors declare that they have no competing interests.

\section{Author details}

${ }^{1} \mathrm{NHC}$ Key Laboratory of Biotechnology of Antibiotics, CAMS Key Laboratory of Synthetic Biology for Drug Innovation, Institute of Medicinal Biotechnology, Chinese Academy of Medical Sciences \& Peking Union Medical College, Beijing 100050, China. ${ }^{2}$ Department of Biomedical Sciences, City University of Hong Kong, Kowloon, Hong Kong, People's Republic of China. ${ }^{3}$ Analytical \& Testing Center, Institute of Medicinal Biotechnology, Chinese Academy of Medical Sciences \& Peking Union Medical College, Beijing 100050, China.

Received: 2 July 2021 Accepted: 9 February 2022

Published online: 08 March 2022

\section{References}

1. Welman AD, Maddox IS. Exopolysaccharides from lactic acid bacteria: perspectives and challenges. Trends Biotechnol. 2003;21:269-74.

2. Fanning S, Hall LJ, Cronin M, Zomer A, MacSharry J, Goulding D, Motherway MO, Shanahan F, Nally K, Dougan G, van Sinderen D. Bifidobacterial surface-exopolysaccharide facilitates commensal-host interaction through immune modulation and pathogen protection. Proc Natl Acad Sci U S A. 2012;109:2108-13.

3. Wu Q, Wu JB, Li Y. Screening, purification and pharmacological study on a IL-1R antagonist-Streptomyces sp.139. Chinese J Antibiot. 1999;26:401-3.

4. Chen J, Wu JB, Liu YM, Xu GY. Study on the structural property of polysacchrides 139A-a kind of IL-1R antagonists from microorganism. Yao Xue Xue Bao. 2001;36:787-9.

5. Wang LY, Li ST, Li Y. Identification and characterization of a new exopolysaccharide biosynthesis gene cluster from Streptomyces. FEMS Microbiol Lett. 2003;220:21-7.

6. Bai L, Chang M, Shan J, Jiang R, Zhang Y, Zhang R, Li Y. Identification and characterization of a novel spermidine/spermine acetyltransferase encoded by gene ste26 from Streptomyces sp. 139. Biochimie. 2011;93:1401-7.

7. Zhang Y, Zhou J, Chang M, Bai L, Shan J, Yao C, Jiang R, Guo LH, Zhang $R, W u$ JB, Li Y. Characterization and functional evidence for Ste27 of 
Streptomyces sp. 139 as a novel spermine/ spermidine acetyltransferase. Biochem J. 2012;443:727-34.

8. Al-Shawi MK. Catalytic and transport cycles of $A B C$ exporters. Essays Biochem. 2011;50:63-83.

9. Shin SK, Park HS, Kwon HJ, Yoon HJ, Suh JW. Genetic characterization of two S-adenosylmethionine-induced ABC transporters reveals their roles in modulations of secondary metabolism and sporulation in Streptomyces coelicolor M145. J Microbiol Biotechnol. 2007;17:1818-25.

10. Davidson AL, Chen J. ATP-binding cassette transporters in bacteria. Annu Rev Biochem. 2004;73:241-68.

11. Schlösser A, Jantos J, Hackmann K, Schrempf H. Characterization of the binding protein-dependent cellobiose and cellotriose transport system of the cellulose degrader Streptomyces reticuli. Appl Environ Microbiol. 1999;65:2636-43.

12. van Wezel GP, White J, Bibb MJ, Postma PW. The malEFG gene cluster of Streptomyces coelicolor A3(2): characterization, disruption and transcriptional analysis. Mol Gen Genet. 1997;254:604-8.

13. Xiao X, Wang F, Saito A, Majka J, Schlösser A, Schrempf H. The novel Streptomyces olivaceoviridis ABC transporter Ngc mediates uptake of $\mathrm{N}$-acetylglucosamine and N. N'-diacetylchitobiose Mol Genet Genomics. 2002;267:429-39.

14. Tsujibo H, Kosaka M, Ikenishi S, Sato T, Miyamoto K, Inamori Y. Molecular characterization of a high-affinity xylobiose transporter of Streptomyces thermoviolaceus OPC-520 and its transcriptional regulation. J Bacteriol. 2004;186:1029-37.

15. Saito A, Fujii T, Shinya T, Shibuya N, Ando A, Miyashita K. The msiK gene, encoding the ATP-hydrolysing component of $\mathrm{N}, \mathrm{N}^{\prime}$-diacetylchitobiose $A B C$ transporters, is essential for induction of chitinase production in Streptomyces coelicolor A3(2). Microbiology. 2008;154:3358-65.

16. Seo JW, Ohnishi Y, Hirata A, Horinouchi S. ATP-binding cassette transport system involved in regulation of morphological differentiation in response to glucose in Streptomyces griseus. J Bacteriol. 2002;184:91-103

17. Bai L, Jiang R, Guo L, Zhang Y, Li Y. The effects of ste 3 and ste 4 Genes Double Disruption in Ebosin Biosynthesis. China Biotechnol. 2015;35:23-8.

18. Ai L, Geng M, Ma M, Bai L. Complete genome sequence of the ebosinproducing strain Streptomyces sp. 139. Microbiol Resour Announc. 2019;8:e01283-19.

19. Hsiao NH, Kirby R. Comparative genomics of Streptomyces avermitilis, Streptomyces cattleya, Streptomyces maritimus and Kitasatospora aureofaciens using a Streptomyces coelicolor microarray system. Antonie Van Leeuwenhoek. 2008;93:1-25.

20. Bentley SD, Chater KF, Cerdeño-Tárraga AM, Challis GL, Thomson NR, James KD, Harris DE, Quail MA, Kieser H, Harper D, Bateman A, Brown S, Chandra G, Chen CW, Collins M, Cronin A, Fraser A, Goble A, Hidalgo J, Hornsby T, Howarth S, Huang CH, Kieser T, Larke L, Murphy L, Oliver K, O'Neil S, Rabbinowitsch E, Rajandream MA, Rutherford K, Rutter S, Seeger K, Saunders D, Sharp S, Squares R, Squares S, Taylor K, Warren T, Wietzorrek A, Woodward J, Barrell BG, Parkhill J, Hopwood DA. Complete genome sequence of the model actinomycete Streptomyces coelicolor A3(2). Nature. 2002;417:141-7.

21. Ohnishi Y, Ishikawa J, Hara H, Suzuki H, Ikenoya M, Ikeda H, Yamashita A, Hattori M, Horinouchi S. Genome sequence of the streptomycinproducing microorganism Streptomyces griseus IFO 13350. J Bacteriol. 2008;190:4050-60.

22. Qi X, Sun Q, Bai L, Shan J, Zhang Y, Zhang R, Li Y. Identification of a-D-glucose-1-phosphate cytidylyltransferase involved in Ebosin biosynthesis of Streptomyces sp. 139. Appl Microbiol Biotechnol. 2009;83:361-8.

23. Wang L, Feng Z, Wang $X$, Wang $X$, Zhang X. DEGseq: an R package for identifying differentially expressed genes from RNA-seq data. Bioinformatics. 2010;26:136-8.

24. Pérez-Mendoza D, Sanjuán J. Exploiting the commons: cyclic diguanylate regulation of bacterial exopolysaccharide production. Curr Opin Microbiol. 2016;30:36-43.

25. Römling U, Galperin MY, Gomelsky M. Cyclic di-GMP: the first 25 years of a universal bacterial second messenger. Microbiol Mol Biol Rev. 2013;77:1-52.

26. Chou SH, Galperin MY. Diversity of Cyclic Di-GMP-Binding Proteins and Mechanisms. J Bacteriol. 2016;198:32-46.
27. Figge RM, Divakaruni AV, Gober JW. MreB, the cell shape-determining bacterial actin homologue, co-ordinates cell wall morphogenesis in Caulobacter crescentus. Mol Microbiol. 2004;51:1321-32.

28. Mazza P, Noens EE, Schirner K, Grantcharova N, Mommaas AM, Koerten HK, Muth G, Flärdh K, van Wezel GP, Wohlleben W. MreB of Streptomyces coelicolor is not essential for vegetative growth but is required for the integrity of aerial hyphae and spores. Mol Microbiol. 2006;60:838-52.

29. Singh R, Wiseman B, Deemagarn T, Jha V, Switala J, Loewen PC. Comparative study of catalase-peroxidases [KatGs]. Arch Biochem Biophys. 2008;47:207-14.

30. Yamashita M, Shepherd M, Booth WI, Xie H, Postis V, Nyathi Y, Tzokov SB, Poole RK, Baldwin SA, Bullough PA. Structure and function of the bacterial heterodimeric $A B C$ transporter CydDC: Stimulation of ATPase activity by thiol and heme compounds. J Biol Chem. 2014:289:23177-88.

31. Schmid J, Sieber V, Rehm B. Bacterial exopolysaccharides: biosynthesis pathways and engineering strategies. Front Microbiol. 2015;6:496.

32. Cheng X, Zheng X, Zhou X, Zeng J, Ren Z, Xu X, Cheng L, Li M, Li J, Li Y. Regulation of oxidative response and extracellular polysaccharide synthesis by a diadenylate cyclase in Streptococcus mutans. Environ Microbiol. 2016;18:904-22.

33. van Dissel D, Willemse J, Zacchetti B, Claessen D, Pier GB, van Wezel GP. Production of poly- $\beta-1,6-N$-acetylglucosamine by Mat $A B$ is required for hyphal aggregation and hydrophilic surface adhesion by Streptomyces. Microb Cell. 2018;5:269-79.

34. Colson S, van Wezel GP, Craig M, Noens EE, Nothaft $H$, Mommaas AM, Titgemeyer F, Joris B, Rigali S. The chitobiose-binding protein, DasA, acts as a link between chitin utilization and morphogenesis in Streptomyces coelicolor. Microbiology. 2008;154:373-82.

35. Rigali S, Titgemeyer F, Barends S, Mulder S, Thomae AW, Hopwood $D A$, van Wezel GP. Feast or famine: the global regulator DasR links nutrient stress to antibiotic production by Streptomyces. EMBO Rep. 2008:9:670-5.

36. Świątek-Połatyńska MA, Bucca G, Laing E, Gubbens J, Titgemeyer F, Smith CP, Rigali S, van Wezel GP. Genome-wide analysis of in vivo binding of the master regulator DasR in Streptomyces coelicolor identifies novel non-canonical targets. PLoS One. 2015;10:e0122479.

37. Saito A, Shinya T, Miyamoto K, Yokoyama T, Kaku H, Minami E, Shibuya N, Tsujibo H, Nagata Y, Ando A, Fujii T, Miyashita K. The dasABC gene cluster, adjacent to dasR, encodes a novel $\mathrm{ABC}$ transporter for the uptake of N, N'-diacetylchitobiose in Streptomyces coelicolor A3(2). Appl Environ Microbiol. 2007:73:3000-8.

38. Urem M, Świątek-Połatyńska MA, Rigali S, van Wezel GP. Intertwining nutrient-sensory networks and the control of antibiotic production in Streptomyces. Mol Microbiol. 2016;102:183-95.

39. Bai L, Qi X, Zhang Y, Yao C, Guo L, Jiang R, Zhang R, Li Y. A new GntR family regulator Ste1 in Streptomyces sp. 139. Appl Microbiol Biotechnol. 2013;97:8673-82.

40 Kieser T, Bibb MJ, Butter MJ, Chater KF. Hopwood DA. Practical Streptomyces genetics. The John Innes Foundation. England: Norwich; 2000.

41. Sambrook J, Russel DW. Molecular cloning, a laboratory manual. New York: Cold Spring Harbor: Cold Spring Harbor Laboratory Press; 2001.

42. Ishikawa J, Hotta K. Nucleotide sequence and transcriptional start point of the kan gene encoding an aminoglycoside 3-N-acetyltransferase from Streptomyces griseus SS-1198PR. Gene. 1991;108:127-32.

43. Bierman M, Logan R, O'Brien K, Seno ET, Rao RN, Schoner BE. Plasmid cloning vectors for the conjugal transfer of DNA from Escherichia coli to Streptomyces spp. Gene. 1992;116:43-9.

44. MacNeil DJ, Gewain KM, Ruby CL, Dezeny G, Gibbons PH, MacNeil T. Analysis of Streptomyces avermitilis genes required for avermectin biosynthesis utilizing a novel integration vector. Gene. 1992;111:61-8.

45. Zhang T, Wang L, Xu G, Chen Y, Zhang Y, Li Y. Disruption of ste23 gene affects composition profile and bioactivity of exopolysaccharide produced by Streptomyces sp. 139. Lett Appl Microbiol. 2006:42:132-7.

46. Jing C, Jianbo W, Yuan L, Rong J, Baoyi L. A new IL-1 receptor inhibitor 139A: fermentation, isolation, physico-chemical properties and structure. J Antibiot. 2003;569(2):87-90.

47. Li H, Zhou H, Luo Y, Ouyang H, Hu H, Jin C. Glycosylphosphatidylinositol [GPI] anchor is required in Aspergillus fumigatus for morphogenesis and virulence. Mol Microbiol. 2007;64:1014-27. 
48. Clinical and Laboratory Standards Institute. Methods for dilution antimicrobial susceptibility tests for bacteria that grow aerobically; approved standard —eighth edition. CLSI document M07-A8. Wayne, PA: Clinical and Laboratory Standards Institute; 2009.

\section{Publisher's Note}

Springer Nature remains neutral with regard to jurisdictional claims in published maps and institutional affiliations.

- fast, convenient online submission

- thorough peer review by experienced researchers in your field

- rapid publication on acceptance

- support for research data, including large and complex data types

- gold Open Access which fosters wider collaboration and increased citations

- maximum visibility for your research: over $100 \mathrm{M}$ website views per year

At BMC, research is always in progress.

Learn more biomedcentral.com/submissions 